\title{
"Abolishing All Mechanisms for Fixing Elections": The Citizens' Initiative to Change the Electoral System of Croatia
}

\author{
ROBERT PODOLNJAK \\ University of Zagreb
}

\begin{abstract}
Summary
In October 2014 a citizens' initiative called 'In the Name of the Family' collected more than 380,000 signatures demanding a constitutional referendum on comprehensive electoral reform in Croatia. The Initiative aimed to introduce preferential voting for MPs; new criteria for the establishment of electoral constituencies; a lower electoral threshold from five to three per cent; a ban on pre-electoral coalitions and joint lists of several parties; and postal and electronic voting. The constitutional referendum demanded by the initiative was not held due to the organizers collecting an insufficient number of signatures for the referendum petition to be valid, and only a limited reform of the electoral system was enacted with the introduction of preferential voting for MPs. What had started as a bottom-up citizens' initiative (or 'mass imposition' in Renwick's terminology) finally ended as an 'elite majority imposition' of an electoral reform.
\end{abstract}

Keywords: Citizens' Initiative, Electoral System, Croatia, Referendum, Civil Society

\section{Introduction}

According to Freedom House reports, Croatia finally established itself as a 'free' country only after parliamentary elections held in January 2000 were conducted in a free and fair manner (Jasic, 2000), and after it underwent a constitutional transformation from a semi-presidential to a parliamentary system in November of the same year. As the latest (28th) member state of the EU, Croatia confirmed its democratic credentials after it had fulfilled all the necessary criteria for accession (democratic institutions, the rule of law, protection of human rights, and respect for minority rights) (Balkir \& Aknur, 2015). According to the Freedom House classifications, 
Croatia is an electoral democracy (Freedom in the World, 2013) and "there are no constraints on free and fair elections" (Balkir \& Aknur, 2015: 87). ${ }^{1}$

In the last four parliamentary elections, i.e. since 2000, Croatia has used the same electoral system for the election of its parliament (the Croatian Sabor). According to the Constitution, the parliament shall have no less than 100 and no more than 160 members elected on the basis of direct, universal and equal suffrage by secret ballot for a four-year term (The Constitution of the Republic of Croatia, Art. 72). The Act on the Election of Representatives to the Croatian Parliament regulates the number of representatives and the manner in which they are elected.

In brief, Croatia has a proportional electoral system with 10 large regional electoral constituencies. In each territorial constituency, 14 representatives are elected from closed party or independent lists. The electoral threshold for the allocation of mandates applied at the level of the electoral constituencies amounts to 5 per cent. Additionally, there are two non-territorial electoral constituencies, from which three diaspora representatives (see Kasapović, 2012) and eight national minority representatives (see Omejec, 2004) are elected.

This electoral system has helped both major parties (i.e., the centre-right Croatian Democratic Union and the centre-left Social Democratic Party) win the elections twice and is, therefore, perceived to be fair and legitimate, at least by the said governing parties. This is also why scholars in Croatia hold that the electoral system is basically satisfactory (Kasapović, 2013).

The Final Report on the 2011 parliamentary elections in Croatia by the OSCE/ ODIHR Election Observation Mission states that "overall, the legal framework provides a sound basis for the conduct of democratic elections", that "candidate registration was inclusive and provided voters with distinct political alternatives", that the elections "took place in a pluralistic environment and were administered in an efficient and transparent manner", that "most aspects of the electoral process enjoyed a high degree of public confidence", and that "the State Election Commission performed its duties in a collegial and transparent manner and was trusted and considered impartial by the vast majority of electoral stakeholders" (OSCE/OHIDR, 2012).

However, there were some recommendations made to the Croatian authorities with regard to the improvement of the electoral process, in particular with regard to the legal framework and the compilation of voter lists. The most important remark in the Report was that "the equality of the vote is undermined by the current delimitation of constituencies, which has not been revised since the adoption of the Act on

${ }^{1}$ On the concept of 'free and fair' elections see Elklit and Svensson (1997) and Goodwin-Gill (1994). 
Constituencies in 1999". Although the Act on the Election of Representatives to the Croatian Parliament prescribes that the number of registered voters in the ten territorial constituencies should not differ by more than 5 per cent, the final voter lists for the 2011 elections indicated variations of up to 33 per cent (ibid.: 5). The OSCE/ ODIHR Mission also states that the Croatian Constitutional Court had issued a notification on this topic with recommendations to the Croatian Parliament before the last parliamentary elections. This Notification on the Unequal Weight of Vote in the Constituencies for the Election of Members of the Croatian Parliament was issued by the Constitutional Court in December 2010, less than a year before the upcoming parliamentary elections. ${ }^{2}$ Accordingly, the public expected that the new parliament would address this issue as a priority, but in vain.

But then in October 2014, wholly unexpectedly, almost three years after the 2011 parliamentary elections, a citizens' initiative called 'In the Name of the Family' collected more than 380,000 signatures demanding a constitutional referendum on a comprehensive electoral reform in Croatia. The Initiative aimed to introduce preferential voting for MPs, new criteria for the establishment of electoral constituencies, to lower the electoral threshold from five to three per cent, to ban preelectoral coalitions and joint lists of several parties, and to introduce postal and electronic voting. It must immediately be said that the constitutional referendum demanded by the Initiative was not held due to organizers' collecting an insufficient number of signatures for the referendum petition to be valid, and only a limited reform of the electoral system was enacted with the introduction of preferential voting for MPs. What had started as a bottom-up citizens' initiative (or 'mass imposition' in Renwick's terminology) finally ended as an 'elite majority imposition' of an electoral reform (Renwick, 2010).

This article examines the genesis and goals of the said Croatian citizens' initiative to reform the electoral system, and the possibility of eliminating electoral engineering by major parties with similar interests through popular initiatives.

The purpose of this paper is, firstly, to analyze the origins of the electoral reform movement in Croatia, and the role of the popular initiative as a vehicle of this reform. Secondly, it is important to analyze why the initiative organization succeeded in mobilizing the people on the subject of electoral reform, arguing that the existing legal framework for parliamentary elections represents a manipulative system with major flaws, but changing it is not in the interest of the major parliamentary parties since the system was created by them. Thirdly, given that the most radical idea of the entire reform was to prescribe the fundamental principles of the electoral system in the Constitution and not in legislation, I ask what were the most important

2 The text of the Notification is available in English at www.sabor.hr/fgs.axd?id=18505. 
arguments on the issue of the constitutionalization of the electoral system? Finally, if, according to foreign election observers, the existing Croatian constitutional and legislative framework guarantees 'free and fair' elections and complies, generally, with international electoral standards, how could it be that it is perceived by voters to be problematic from the standpoint of electoral integrity? The paper argues that the problem lies in international electoral standards that are not sufficiently rigorous in prescribing rules, or at least guidelines or recommendations that would place far more emphasis on respect for the principles of direct and equal suffrage, the existence of democratic, multiparty systems, equal opportunities for political parties in electoral competition, the free expression of popular will, and the broad representativeness of the parliament in the establishment of the electoral system of a given country.

\section{Citizens' Initiative in the Croatian Constitutional System}

Although the institution of holding referendums is well established as a means of direct decision-making of the people in most European countries, it is equally true that the institution of holding citizen-initiated referendums is rare in the older West European countries - only Switzerland and Italy (and the tiny Lichtenstein) have different forms of citizen-initiated referendums. On the other hand, almost all newly adopted East European constitutions provide for various instruments of direct democracy (Brunner, 2001: 222).

The original Croatian Constitution adopted in 1990 envisaged only facultative referendums on constitutional or legislative matters (Art. 86 of the original Constitution, which is today Art. 87). ${ }^{3}$ The Croatian Parliament may call a referendum on a proposal for the amendment of the Constitution, on a bill, or any other issue within its competence. The President of the Republic may, at the proposal of the Government and with the countersignature of the Prime Minister, call a referendum on a proposal for the amendment of the Constitution or any other issue which he/she considers to be important for the independence, unity and existence of the Republic of Croatia. ${ }^{4}$ Neither the Parliament nor the President has ever called a referendum on a proposal for the amendment of the Constitution.

A great change happened in 2000 , when popular initiative was constitutionalized. At the proposal of a small parliamentary party (the Croatian Party of Rights), whose votes were necessary for the two-thirds parliamentary majority to accomplish

3 The only obligatory referendum prescribed in the Croatian Constitution is referendum on the association or disassociation of the Republic of Croatia into alliances with other states.

${ }^{4}$ An analysis of the original constitutional design of referendum may be found in Rodin (2001). 
the most significant constitutional transformation, one that would change Croatia's original semi-presidential system into a parliamentary system, Article 86 was amended, prescribing that the Croatian Parliament shall call a referendum on all issues that may be put to a referendum by the Croatian Parliament or the President when so demanded by ten per cent of all voters in the Republic of Croatia. With this constitutional provision, Croatian citizens acquired the full-scale popular constitutional initiative, i.e. the ability to demand a constitutional referendum (see Podolnjak, 2014b). This is, arguably, the most radical instrument of citizen involvement in constitution-making and constitution-amending, much more radical than constituent assemblies elected by citizens or the simple acceptance of a constitution proposed by a parliament in a referendum.

To date, the most successful citizens' initiative in Croatia was the initiative of the 'In the Name of the Family' organization backed by the Catholic Church calling for a referendum on the following question: "Are you in favor of the Constitution of the Republic of Croatia being amended with a provision stating that marriage is a life union between a woman and a man?" The initiative was a response to the Government's alleged plans to legalize same-sex marriage. In May 2013, the initiative organization officially collected 683,948 signatures, thereby fulfilling the basic condition to hold the first citizen-initiated constitutional referendum in Croatia. The referendum was held in December 2013. With a relatively modest turnout of 37. 9\%, almost twothirds of voters $(946,433$ or $65.87 \%$ ) voted for amending the Constitution with the inclusion of the definition of marriage as a union of man and woman. ${ }^{5}$

It came as no surprise when in June 2014 'In the Name of the Family' announced that it would start collecting signatures for the calling of another constitutional referendum, but this time on the issue of the electoral reform. ${ }^{6}$ That a conservative religious organization would be interested in proposing far-reaching reforms of the parliamentary election system in Croatia was not expected. ${ }^{7}$

5 The State Electoral Commission of the Republic of Croatia, The Report on the National Referendum held on December 1, 2013, available at http://www.izbori.hr/izbori/dip_ws.nsf/0/1E 214A4855D86146C1257C3D00410D9F/\$file/Izvjesce_o_provedenom_drzavnom_referendumu_0122013.pdf (last accessed on December 20, 2013).

${ }^{6}$ See 'Croat Family Values Group Demand Electoral Reform', Balkan Insight, 12 June 2014, available at http://www.balkaninsight.com/en/article/ngo-initiate-referendum-for-electoral-reform-in-croatia.

7 There were accusations made by several political parties that the leaders of the Initiative have political ambitions and that their referendum activities are just a prelude to their future political activities, but this has not been confirmed so far. 


\section{Preferential Voting for the European Parliament Elections as the Immediate Motive for an Electoral Reform}

Why did the issue of electoral reform suddenly generate such interest with the citizens' Initiative, but also, as we shall see, with the wider public in Croatia?

The immediate motive for the electoral reform referendum pertained to the European Parliament elections held in Croatia in April 2013 and again in May 2014. These were the first elections in Croatia in which the voters could cast a preference vote for a candidate on a party or independent list. Although the preferential voting system introduced for the election of representatives to the EP from Croatia had only a limited effect on the question of which candidate from a party list would be elected (because each voter could cast only one preference vote, and because candidates also had to satisfy the condition of receiving at least 10 per cent of all votes given to their list, which was a threshold for counting preference votes as relevant for determining the order of elected candidates), it was accepted by Croatian voters as an opportunity to cast their vote directly to a preferred candidate, and not just to a party.

Logically, the public expected the Parliament to legislate the introduction of preferential voting for the Croatian Sabor before the next parliamentary elections due to take place in late 2015. Everyone thought that, if voters could vote directly for EP representatives, it is absolutely logical and necessary that they should also have the same right when it comes to national elections. However, the governing coalition (but also the main opposition party) had declined to respond to this public appeal. It was at this particular moment, just a few months after the EP elections, that the initiative organization 'In the Name of the Family' announced its plan to call for a constitutional referendum on electoral reform.

The existing electoral system is, according to the leaders of the initiative organization, unconstitutional, unfair, unrepresentative and unresponsive to voters in many ways. Its major flaws ${ }^{8}$ are the following:

1) The electoral system, stipulated by law, is made by and serves only the interests of major parties, and voters have no influence on shaping its main features.

2) Voters are presented an opportunity only to vote for closed party lists, because of which the responsibility of the representatives elected is not to voters. They are perceived only as party pawns in the Parliament. According to 'In the Name of the Family', the compliance of voting for a party list with the constitutional requirement that representatives should be elected on the 'basis of direct suffrage' is questionable.

${ }^{8}$ On the major flaws of the Croatian electoral system see also Podolnjak (2012). 
3) The electoral system is unfair because the electoral threshold of 5 per cent resulted in more than 600,000 votes wasted in the last parliamentary elections. ${ }^{9}$ This means that every fourth voter who voted in the elections is not represented in the Parliament by any party. Thus, the Parliament lacks representativeness. Moreover, this mainly benefits the major parties given that they, undeservedly, received additional seats that did not correspond to their vote share. The 5 per cent threshold enabled the majority pre-electoral coalition of parties to receive 55 per cent of seats with only 40 per cent of votes.

4) The system is also unfair because it allows pre-electoral party coalitions, which means that voters cannot vote for a preferred party, but only for a prearranged coalition. In this case, voting for a coalition can help to elect representatives not only from small parties that would not pass the electoral threshold independently, but also from parties of different ideologies. ${ }^{10}$ The two dominant parties (the Social Democratic Party and the Croatian Democratic Union), as leaders of two pre-electoral coalitions, are, therefore, the hegemons of the system, and it is they who decide whether a particular party shall be invited to join a pre-electoral coalition. Parties outside coalitions have far less chance of passing the relatively high electoral threshold.

5) As already mentioned, the existing electoral system also violates the fundamental constitutional principle of the equality of each vote because of a large discrepancy in the number of voters between the electoral constituencies. This remark was particularly relevant because the Croatian Parliament has not done anything to change the Croatian Parliamentary Election Constituency Act, despite the Notification from the Constitutional Court and the recommendations of the OSCE Election Observation Mission.

As to specific variables measuring different dimensions of electoral integrity over electoral cycles according to the Electoral Integrity Project (see Norris, Frank and Martinez i Coma, 2013), it is obvious that the arguments of the initiative organization emphasized electoral malpractices related to electoral laws and boundaries, ${ }^{11}$ claiming that the current Croatian electoral law is unfair to smaller parties, that it

9 Electoral threshold belongs, as remarked by Pippa Norris, to the category of "more subtle and legal techniques that also violate international standards (that) are often employed well away from the public spotlight" (Norris, 2014a: 64).

${ }^{10}$ It is not unusual in Croatia that pre-electoral coalitions are made of parties which belong to different party families (e.g., the current centre-right coalition is made of parties which would, in the European context, belong to the Christian democratic, conservative, liberal and far-right group of parties).

11 This corresponds to Elklit's term 'systemic manipulation' (Elklit, 2012), or Birch's term 'manipulation of institutions' (Birch, 2011). 
favors the governing parties, that it restricts citizens' rights, and finally that the boundaries of electoral constituencies discriminate against some parties and violate the principle of equal voting power.

\section{The Goals of the Electoral Reform Initiative: Ending Electoral Engineering as a Form of Electoral Manipulation}

Electoral reform was initiated with the goal of ending the electoral engineering of major parties or, to quote the leader of the civil society group, "abolishing all mechanisms for fixing elections in Croatia". Željka Markić, the leader behind the initiative, argued that it is "important to break electoral engineering and to facilitate that Croatia, as an EU member state, should fulfill the same electoral standards as other developed democracies". ${ }^{2}$

Before the Initiative formally announced that it would initiate a constitutional referendum on reforming the electoral system, I was invited by the organizing committee behind the Initiative as a legal adviser to participate in the drafting of the referendum question. The reason for this was that $I$ have been recognized in the public as a strong critic of the existing electoral system and my views on the subject have largely been accepted by the initiative organization. I, therefore, agreed to participate in drafting the constitutional amendment that would be incorporated in the referendum question.

Electoral engineering as a sophisticated form of electoral manipulation has been present in Croatia in various forms for the last 20 years. In the first decade after gaining independence, the Croatian Parliament changed electoral legislation prior to all parliamentary elections, making Croatia the only new democracy that used three different electoral systems within a relatively short period of time: a tworound majority system, a plurality voting system and a proportional representation system. However, it must be said that the electoral law enacted in late 1999 has not been changed with respect to the main features of the electoral system. In 1995, the Croatian Parliament 'invented' separate seats for the diaspora, i.e. Croatian citizens who live abroad, although the number of diaspora MPs has changed several times, ranging from 12 to 3 (see Kasapović, 2012). The Parliament also changed the legal threshold for single parties or coalitions several times. In the current Act, the electoral threshold is set at 5 per cent of valid votes at the level of the electoral constituency, and it is because of this threshold that more than 25 per cent of votes in the last parliamentary elections were wasted.

12 "Dr. Željka Markić: Svi mehanizmi namještanja rezultata izbora u Hrvatskoj trebaju se ukinuti!" (All Mechanisms for Fixing Elections in Croatia Should be Abolished!), available at http:// narod.hr/izdvojen-clanak/dr-zeljka-markic/. 
Election law in Croatia belongs to the category of organic laws, which means that a majority of all representatives is needed for it to be enacted. However, this majority is not too difficult to reach - it requires only that the governmental majority solidly backs the law.

After twenty years of democratic transition, after the consolidation of democratic institutions, and bearing in mind that Croatia was at the entrance of the EU membership club, one would expect governing politicians to at least try to control their impulse to use electoral engineering as a legal form of electoral manipulation. However, shortly before the last parliamentary elections in 2011, several changes of the Act on the Election of Representatives to the Croatian Parliament were either attempted or implemented concerning the election of diaspora representatives, representatives of the largest national minority, and the redrawing of the boundaries of the electoral districts which were examples par excellence of electoral engineering in a negative sense and very harmful from the point of view of constitutionalism, democracy and the legitimacy of parliamentary decision-making. ${ }^{13}$ Croatia's experience of the last 20 years shows that the legal barriers to electoral engineering in Croatia have not been strong enough.

Numerous constitutional and political analyses see electoral engineering as a form of constitutional engineering (Eckstein, 1963), ${ }^{14}$ despite the fact that electoral systems are not included in the majority of modern constitutional texts. However, as remarked over 60 years ago by Luigi Sturzo, an Italian politician, "electoral law is, after the constitution, the most important in the institutional order" of the state (Sturzo, 2007: 3).

According to a recent definition, the term 'electoral engineering' is used "to describe the development and implementation of constitutional and legal provisions for electoral system frameworks that are targeted at achieving specific societal goals" (Wall and Salih, 2007: 6). For the supporters of electoral engineering, these goals are associated with the furtherance of democracy, specifically with minimizing the risks of competitive elections, while maintaining their inherent benefits (Moser, 2009). Electoral engineering - changing formal electoral rules - has the capacity to generate major consequences by altering the strategic behavior of politicians, parties and citizens (Norris, 2004: 8).

The fact is that electoral engineering can be a double-edged sword. In a positive sense, electoral engineering is seen as a tool of fostering democracy, ensuring

${ }^{13}$ A part of the Act on the Election of Representatives to the Croatian Parliament, i.e. that pertaining to the election of representatives of the Serb national minority was held unconstitutional by the Constitutional Court (Decision No. U-I-120/2011 from 29 July 2011).

${ }^{14}$ The term 'electoral engineering' was, to my knowledge, first used by Stein Rokkan (1970: 147-168). 
a stable and representative parliamentary government, solving deep societal conflicts, etc. However, I argue that, more often than not, electoral engineering has negative consequences, that it is a sophisticated form of electoral manipulation, and not some neutral and positive sort of institutional engineering. In this sense, the goal of electoral engineering is, in electoral law, to preferentially treat or discriminate in favor of certain actors participating in elections so as to make their electoral victory more probable. ${ }^{15}$ The late William Riker even claimed that "most actual choices (of an electoral system) have been made with the intention of promoting partisan advantage rather than with the goal of incorporating sound constitutional principles into governmental structure" (Riker, 1984: 103). This is why electoral systems are "the most manipulative instrument of politics" (Sartori, 1997: IX). The primary reason why electoral systems are manipulative is the fact that, in most cases, they are not included in constitutional texts, and even when they are in principle, several very important aspects of any electoral system are not (e.g., the regulation of electoral constituencies, electoral thresholds, methods of translation of votes into seats in proportional systems, etc.).

When the electoral system is regulated by an act of parliament, as it is in many countries, it can be enacted with just a simple majority in parliament. This opens the possibility of being tempted to change electoral rules with a view to obtaining benefits which would favor a governing party or a coalition, despite Lijphart's proposition that we should rely on "moral constraints on electoral change" (Lijphart, 1994: 151). There are numerous examples of such manipulation with the basic principles of electoral systems.

Electoral engineering in a negative sense is present in great measure even in established and long-standing democracies as a legal (but not legitimate) tool. Let me point to some recent examples: changing the electoral system in Italy in 2005, a few months before the parliamentary elections (the main provisions of this act were declared unconstitutional by the Italian Constitutional Court in December 2013), ${ }^{16}$ and again in 2015; accusations of gerrymandering by the opposition in the UK (after a

${ }^{15}$ Instead of electoral engineering, Sarah Birch speaks of 'electoral corruption' or 'electoral manipulation'. Manipulation of rules involves the distortion of electoral laws so as to benefit one party or contestant in an election (see Birch, 2009: 396).

${ }^{16}$ In an unexpected and politically controversial decision (Judgment No. 1/2014), the Constitutional Court struck down two provisions of the electoral law, namely the majority prize (premio di maggioranza) and the closed list of party candidates running for election (liste bloccate). The first mechanism gives a majority bonus ( $55 \%$ of the seats) to the relative winner (a single party or a coalition of parties) at the national level (for the House of Representatives) and at the regional level in each of the 20 Regions (for the Senate). The second provision relates to closed party lists, preventing voters from giving preferential votes to candidates on the list (see Duranti, 2014 and Palermo, 2014). 
decrease in the number of MPs in the House of Commons from 650 to 600 with the Parliamentary Voting System and Constituencies Act 2011); ${ }^{17}$ changes of the German electoral law in 2011 after which the opposition parties (i.e., the Social Democrats and the Greens) submitted a constitutional complaint to the Federal Constitutional Court, which declared the law to be unconstitutional in July 2012, etc. ${ }^{18}$

If, as we have seen, long-established democracies are not immune to using electoral law as a tool of political manipulation, finding the same in the new democracies of the post-communist world in even greater measure is not surprising.

The most recent example of electoral engineering is observed in Hungary. According to an analyst, "using its supermajority, Fidesz has gerrymandered a number of electoral districts and rewritten the election laws in a way that favors big, unified parties rather than the fractured opposition". ${ }^{19}$

What are the legal and political remedies for electoral engineering that are likely to prevent or at least greatly limit the political manipulation of electoral rules? Constitutional or supreme courts could, in some situations, prevent unconstitutional manipulations of electoral rules, but in most cases courts cannot intervene in the sense of blocking negative electoral engineering.

\section{Constitutionalization of the Electoral System through Referendum and Popular Initiative}

Some other solutions can also be recommended (see Podolnjak, 2013). The first solution for preventing negative electoral engineering is through the constitutionalization of the electoral system, ${ }^{20}$ i.e. by inserting some basic principles of the electoral

However, the new electoral law looks like another 'electoral engineering' project - the leaders of the two major, yet opposing Italian parties, Matteo Renzi (Democratic Party) and Silvio Berlusconi (Forza Italia), have allegedly struck a bargain over the enactment of the new law favoring both parties. See "Italian reform: Renzi's tricky bargain", The Economist, 25 January 2014.

${ }^{17}$ However, the proposed reduction of MPs is postponed until 2018 at the earliest, given that the plans to redraw constituency boundaries were defeated in the House of Commons in January 2013 due to the opposition's (i.e., the Labour Party, the Liberal Democrats and other small parties) unified stand. See "Conservatives lose boundary review vote", http://www.bbc.co.uk/news/ uk-politics-21235169.

18 On flawed contests in consolidated democracies see also Norris (2014a: 150-151).

19 "Hungarian politics: Against the odds", The Economist, 25 January 2014.

${ }^{20}$ Pippa Norris advances seemingly the same argument by stating that "a way to insulate electoral law from manipulation by incumbents is to entrench it in higher law", but she refers only to the constitutionalization of "administration, adjudication and enforcement of elections" (Norris, 2014b: 13). However, by the constitutionalization of the electoral system I do not mean the constitutionalization of election management (on this see Chernykh, Elkins, Melton and Ginsburg, 2014: 94-117). 
system into the constitution (Podolnjak, 2014a). ${ }^{21}$ This would require, as a rule, that the governing and main opposition parties reach an agreement on the basic principles of the electoral system. However, this solution has its shortcomings, because it cannot prevent the possibility of constitutionalizing electoral rules designed by major parliamentary parties against small and/or non-parliamentary parties if the constitution can be changed only by a qualified majority vote in parliament.

The second solution, which is more preferable in my opinion, is constitutionalizing the basic principles of the electoral system through a constitutional referendum, or at least holding a legislative referendum on the issue of electoral reform. The purpose of holding a referendum is to take the final decision on the electoral system out of the hands of party majorities in a legislature. ${ }^{22}$ The role of popular initiatives in many US states regarding some issues of electoral reform (term limits, redistricting, campaign finance, etc.) is very informative (Cain, 2008; Matsusaka, 2006). The experiences of some Canadian provinces (Ontario and British Columbia), with their citizens' assemblies, on electoral reform and subsequent referendums on their proposal are also of relevance (LeDuc, 2011). The two-phased process of selecting an electoral system by the electorate in a referendum process, following New Zealand's model, is also a very good example. Notwithstanding the significant comparative experience with referendums on electoral systems, there is no model which would combine the deliberation of a citizens' assembly with a popular initiative.

However, we have to bear in mind that, in a referendum, voters must choose between simple alternatives, e.g. between the first-past-the-post system, the alternative vote, the German mixed system, the French two-round system or some other electoral system. Asking voters to decide on some important features of proportional systems (e.g., the electoral threshold, the number of electoral constituencies and the average number of representatives to be elected in them, the method of translating votes into seats, etc.) is much more difficult.

Deciding on the choice of the electoral system by referendum, directly or indirectly, is no longer unusual (Qvortrup, 2012). The former leader of the Labour Party, John Smith, said in 1993, after he had received the Plant Report on electoral reform in the UK, that the choice of the electoral system for the House of Commons was too important to be left to politicians: "It is a matter of such constitutional significance that it should be for the people to decide" (Linton and Southcout, 1998: 106). Since the UK 2011 referendum on the alternative vote, it seems that Smith's proposition has been accepted by all parties in the United Kingdom. However, it is

21 On this see the opposite arguments in Taagepera (2002: 260-264).

22 A nice example in the context of the American electoral system is to take the decision-making on drawing of legislative district lines out of the hands of state legislatures and give that authority to independent commissions. 
a paradox of sorts that, in a country without a codified constitution, the electoral system is of such constitutional importance that it could not be left to a parliamentary decision. And one of the best examples of choosing an electoral system via a referendum is arguably New Zealand's model, also in a country without a codified constitution. I have already mentioned the examples of New Zealand and the UK, but there have also been legislative referendums on the electoral system in Slovenia, Romania, Russia, in Italy more than once, and in several other countries. On the other hand, constitutional referendums on the electoral system were held only in Ireland and Switzerland. The proportional electoral system was constitutionalized in Switzerland in 1918 through a popular initiative (see Lutz, 2004).

Let me return to the issue of the constitutionalization of the electoral system. Today, 15 of the 28 EU countries have some basic principles of their electoral system entrenched in their respective constitutions. ${ }^{23}$ Some other non-EU, but European countries, such as Switzerland and Norway, also have their fundamental electoral principles built into their constitutions. The former President of the German Federal Constitutional Court Hans-Jürgen Papier stated recently that the electoral system for the election of people's representatives is one of the most important issues of constitutional law and that it is a great shortcoming of the German Grundgesetz that it has left its regulation to a simple legislator (Papier, 2015: 10). It is interesting to note that the constitutions of countries whose presidents are elected directly or even indirectly generally include detailed presidential election rules, yet brief or even superficial parliamentary election regulations. ${ }^{24}$

\section{Is Negative Electoral Engineering Contrary to the International Electoral Standards?}

Let me repeat the statement of the leader of the aforementioned citizens' initiative organization that it is "important (to call a constitutional referendum) to break electoral engineering and to facilitate that Croatia, as an EU member state, should

${ }^{23}$ The most recent review of electoral systems in EU countries claims that 13 of 27 countries have entrenched their electoral systems in their constitutions (Jesse, 2008: 302). According to this study, these countries are Belgium, Denmark, Estonia, Ireland, Latvia, Luxembourg, Malta, Holland, Austria, Poland, Portugal, Spain and the Czech Republic. However, to my knowledge, three more EU countries have the basic principles of their electoral systems embedded in their constitutions - Slovenia (Article 80 of the Constitution), Sweden in its Instrument of Government (see Chapter 3, Articles 1 to 8) and Finland (Chapter 3, Section 25 of the Constitution). The same mistake as to Sweden and Finland (because Slovenia is left out) may be found in Nohlen (2014: 157). ${ }^{24}$ Bearing in mind the example of the Estonian Constitution, Taagepera notes that "the superficiality of the constitutional stipulations on Riigikogu elections" and the detailed rules on presidential elections, which are "inversely related to the importance of the election, emphasise the lack of overall balanced design in the constitutional kitchen" (Taagepera, 2002: 262). 
fulfill the same electoral standards as other developed democracies". ${ }^{25}$ She did not specify the electoral standards she referred to, which are presumably fulfilled in the developed EU member states. However, she would be surprised to know that international electoral standards are too 'lax' to prevent most significant manipulations of legal rules related to the design of an electoral system. ${ }^{26}$

As admitted by Pippa Norris, "every election is 'manipulated', even in the most democratic states, in the sense that all contain legal mechanisms, vote thresholds, and formula that translate votes into seats, determining winners and losers". However, she also admits that it is not self-evident what types of manipulation are acceptable or unacceptable from the standpoint of electoral integrity and that this "requires a broader normative theory" (Norris, 2014a: 8). She states correctly that the foundation of the modern concept of electoral integrity rests on "international conventions and universal standards about elections reflecting global norms applying to all countries throughout the electoral cycle" (ibid.: 21). The problem is, in my opinion, that these standards are very much developed only in terms of protecting the principles of universal, secret and equal ${ }^{27}$ suffrage, and the right to participate in elections (both as a voter and a candidate) which reflects the free expression of the will of the people, but do not go far enough in assuring that electoral systems and electoral rules (particularly for a representative body) respect the principles of a direct and equal vote, equal opportunities for political parties, and the broad representation of different societal groups in parliament, as these principles are elaborated later, e.g. in the jurisprudence of the constitutional courts of Germany or Italy (see Chryssogonos and Stratilatis, 2012).

It is fair to say that the European standards protecting the right to free elections ${ }^{28}$ resting on the judicial protection of this right (the European Court of Human Rights), provide a strong normative basis for the protection of the right to

25 "Dr. Željka Markić: Svi mehanizmi namještanja rezultata izbora u Hrvatskoj trebaju se ukinuti!" (All Mechanisms for Fixing Elections in Croatia Should be Abolished!), available at http:// narod.hr/izdvojen-clanak/dr-zeljka-markic/.

${ }^{26}$ This could explain Sarah Birch's conclusion that it can be expected from political leaders to opt for the manipulation of rules and institutions because these forms of electoral manipulation carry the least risk. Her explanation is worth citing: "Rules can be altered through legal means and though international legal standards have been developed in this sphere, state actors nevertheless enjoy considerable leeway in the interpretation of international norms" (Birch, 2011: 30-31, 60-61, 71-88).

${ }^{27}$ In the sense of the 'one person, one vote' principle.

${ }^{28}$ Article 3 of Protocol No. 1 to the Convention for the Protection of Human Rights and Fundamental Freedoms: "The High Contracting Parties undertake to hold free elections at reasonable intervals by secret ballot, under conditions which will ensure the free expression of the opinion of the people in the choice of the legislature". In the Recommendation 1898 (2010) of the Parliamentary Assembly, it is even stated that the Council of Europe area establishes the world's largest "free and fair election zone". 
vote and the right to stand as a candidate in elections. However, as recently admitted, "the Court's constant position is that states have a wide latitude to design their own electoral systems to suit the particularities of their respective democratic traditions and conditions" (Harris, O'Boyle, Bates and Buckley, 2014: 946). ${ }^{29}$

In the case Mathieu-Mohin and Clerfayt v. Belgium the Court emphasized that Article 3 of the Protocol No. 1

does not create any "obligation to introduce a specific system"... such as proportional representation or majority voting with one or two ballots... the Court recognizes that the Contracting States have a wide margin of appreciation, given that their legislation on the matter varies from place to place and from time to time.

Electoral systems seek to fulfill objectives which are sometimes scarcely compatible with each other: on the one hand, to reflect fairly faithfully the opinions of the people, and on the other, to channel currents of thought so as to promote the emergence of a sufficiently clear and coherent political will. In these circumstances the phrase "conditions which will ensure the free expression of the opinion of the people in the choice of the legislature" implies essentially - apart from freedom of expression... - the principle of equality of treatment of all citizens in the exercise of their right to vote and their right to stand for election.

It does not follow, however, that all votes must necessarily have equal weight as regards the outcome of the election or that all candidates must have equal chances of victory. Thus no electoral system can eliminate "wasted votes". (European Court of Human Rights, 1987: para. 54)

In various cases on different features of electoral systems of interest to this paper, the Court has ruled that, for example, the electoral threshold of 10 per cent is not too excessive "having regard to the specific political context of the elections in question" (Yumak and Sadak v. Turkey, 2008), that the closed-list system had not been in breach of Article 3 of Protocol No. 1 (Saccomanno and others v. Italy, 2012), or that inequalities between electoral constituencies in the number of voters are permissible for the "purpose of accommodating public-interest imperatives and in particular to take account of the "natural realities constituted by certain geographical entities"” (Bompard v. France, 2006). ${ }^{30}$

29 Similarly, Michael O'Boyle, the deputy registrar of the ECHR, stated that "the case law well reflects the reluctance by the Court to meddle in the political or constitutional arrangements of the State, particularly as regards rules concerning parliamentary representation. The Court's approach reveals a certain caution or prudence in imposing a Strasbourg view of how the national constitutional order should function in place of that chosen by the 'people' through national institutions" (O’Boyle, 2008: 1-2).

${ }^{30}$ In the latest book on the Court's jurisprudence on the right to free elections, only three of over 120 pages are dedicated to the Court's decisions on the choice of electoral system and electoral rules (see Lecuyer, 2014: 82-85). 
It is, therefore, not surprising that Yannick Lecuyer suggests - given the Court's view that states have broad discretion when choosing particular electoral systems and electoral rules - that "it is more towards soft law and the work of the Venice Commission than towards European case law that we have to turn" (2014: 103). However, in my opinion, the usefulness of several reports of the Venice Commission on the issues of electoral threshold (Venice Commission, 2008a and 2010) or the latest one on closed/open lists (Venice Commission, 2015) is negligible.

On the issue of the normative basis of electoral system regulation, the recommendation of the Venice Commission in The Code of Good Practice on Electoral Matters is that

one way of avoiding (electoral) manipulation is to define in the Constitution or in a text higher in status than ordinary law the elements that are most exposed (the electoral system itself, the membership of electoral commissions, constituencies or rules on drawing constituency boundaries). Another, more flexible, solution would be to stipulate in the Constitution that, if the electoral law is amended, the old system will apply to the next election - at least if it takes place within the coming year - and the new one will take effect after that. For the rest, the electoral law should normally have the rank of statute law. (Venice Commission, 2008b: 39-40)

The least valuable solution of those recommended in the Code is, in my opinion, that the fundamental elements of electoral law should not be open to amendment less than one year prior to an election (ibid.: 21). I would like to repeat that the recommendation that the most important elements of the electoral system should be defined in the constitution or in a text higher than ordinary law is not good enough, because there can be huge procedural differences between constitutional and statutory regulations of basic elements of electoral systems.

\section{"Let Us Elect Representatives by Name"}

Under the slogan "Let Us Elect Representatives by Name", the citizens' initiative organization collected more than 380,000 signatures, and requested the holding of a constitutional referendum from the Croatian Parliament, with the following referendum question:

"Are you in favor of the adoption of the following constitutional act at a referendum?

CONSTITUTIONAL ACT AMENDING THE CONSTITUTION OF THE REPUBLIC OF CROATIA

\section{Article 1}

In the Constitution of the Republic of Croatia, Article 73 is amended to read:

Representatives in the Croatian Parliament shall be elected for a term of four years. 
Representatives in the Croatian Parliament, other than the representatives of national minorities, shall be elected according to a system of proportional representation. A voter may vote for one of the proposed lists of candidates and may mark up to three candidates having priority over other candidates on the selected list (preferred vote).

Elected candidates from a particular list shall be determined exclusively on the basis of the highest number of preferred votes. If two or more candidates have the same number of preferred votes or if the election of candidates cannot be determined on the basis of preferred votes, the candidate who comes first in the order on the list shall be elected.

Each electoral constituency elects at least 20 representatives. Electoral constituencies may not divide areas that were established by law as the City of Zagreb and the counties of the Republic of Croatia. Seats shall be distributed amongst electoral constituencies based on the calculation of the relations between the number of voters in each electoral constituency and the total number of voters in the Republic of Croatia.

A special act shall be adopted on the areas of electoral constituencies for the election of representatives in the Croatian Parliament.

If an act on the areas of electoral constituencies referred to in the previous paragraph is not adopted, the Republic of Croatia shall make up a single electoral constituency. Voters who do not have registered domicile in the Republic of Croatia shall vote in a special electoral constituency.

Lists that have won at least $3 \%$ of valid votes are eligible for participating in the distribution of seats in the electoral constituency. If the Republic of Croatia makes up a single electoral constituency for the election of representatives, the right to participate in the distribution of seats in the electoral constituency is awarded to lists that have won at least $2 \%$ of valid votes at the elections.

All parties having representatives in the Parliament on the date of publication of the decision announcing elections, and political parties and groups of voters who collect at least 3,000 voters' signatures are entitled to propose party and independent lists for the election of representatives in the Parliament.

Joint lists of two or more political parties are not permitted.

Voters at elections may vote at polling stations, by correspondence or by electronic means.

The manner of electing representatives of national minorities is regulated by an act that regulates the rights of national minorities.

The act sets the number, requirements and the procedure for electing representatives in the Croatian Parliament.

\section{Article 2}

This Constitutional Act shall enter into force on the day of the adoption of a decision on its acceptance at the referendum." 
The referendum question was formulated as a specifically worded proposal. There were several important issues addressed in the constitutional amendment proposal. However, the most important aspects of the proposed electoral reform concerned personalization (the introduction of preferential voting), greater proportionality of the electoral system (larger electoral constituencies and a lower electoral threshold), and a ban of pre-electoral party coalitions.

The referendum petition was strongly opposed by the two largest parties, the ruling Social Democratic Party and the opposition Croatian Democratic Union. They argued that electoral rules are not the subject matter of a constitutional referendum and popular initiatives, but of parliamentary legislation. They also claimed that the electoral reform advocated by the referendum initiative would bring political chaos, the fragmentation of parliament and governmental instability. It was difficult to argue against the introduction of preferential voting, which had already been tested in the European elections twice, or the principles of forming electoral constituencies, so the criticism of the major parties concentrated on two aspects of the proposal - the lowering of the electoral threshold from 5 to 3 per cent, and the ban of pre-electoral coalitions. In their opinion, the lowering of the electoral threshold would lead to a fragmentation of the parliament with many splinter parties. This would, in turn, make the formation of stable government almost impossible. As to the ban of pre-electoral coalitions, the major parties argued that such a ban would be contrary to the constitutional protection of a democratic multiparty system as one of the highest values of the Croatian constitutional order.

The strongest objection to the proposal of the Initiative was that it would cause utter instability and chaos. To quote the chairperson of the parliamentary Committee on the Constitution, Standing Orders and Political System:

What Croatia has with the current electoral system is stability. We have stability in the sense that citizens know how the system works and what it brings to them. We have stability because, every time after elections, it has been relatively easy to form a government. Some other countries have experimented with the electoral system and this has led to great instability. Look at Slovenia and Italy, which every now and then change their electoral system. In Croatia, we do not need political chaos on top of economic instability. ${ }^{31}$

With the support of only some minor parties and trade unions, and with significant hindrances in the process of collecting signatures, the citizens' Initiative collected approximately 380,000 signatures, which were delivered to the Parlia-

31 "Peđa Grbin: The Proposition of 'In the Name of the Family' Would Bring Chaos to Croatia", Novi list, 1 September 2014, available at http://www.novilist.hr/Vijesti/Hrvatska/Peda-Grbin-Prijedlog-U-ime-obitelji-Hrvatskoj-bi-donio-kaos. 
ment requesting that a referendum be called. However, the parliamentary Committee on the Constitution, Standing Orders and Political System stated that the Initiative should have collected over 450,000 signatures, that being the number that corresponds to 10 per cent of all Croatian voters. The problem with the accuracy of voter lists in Croatia is a long-standing one. In particular, it was listed as one of the most problematic aspects of Croatian elections by the OSCE/ODIHR Election Observation Mission (OSCE/ODIHR, 2012: 7-8). ${ }^{32}$

Finally, it was up to the Constitutional Court to decide whether the Initiative had collected the constitutionally prescribed number of signatures. The Court decided that "it is not permissible to call the referendum... because... the calling of the referendum was proposed by 380,649 voters, and it should have been proposed by 404,252 voters, as the Republic of Croatia had 4,042,522 registered voters on 21 September 2014" (The Constitutional Court's decision No. U-VIIR-7346/2014 of 10 December 2014).

Due to the Court's decision, no constitutional referendum on electoral reform was held. However, public pressure to introduce at least some form of preferential voting had been so strong that the governing majority finally backed and in February 2015 enacted the Act on Amendments to the Act on the Election of Representatives to the Croatian Parliament. Limited preferential voting was introduced given that voters may now mark only one candidate on the ballot to have precedence over other candidates on the slate selected, and these preferential votes cast for individual candidates are taken into account if a particular candidate's number of preference votes is at least $10 \%$ of the votes won by a particular slate. Croatia uses the same model for European Parliament elections.

\section{Conclusion}

The introduction of a limited preferential voting system for national parliamentary elections in Croatia has been perceived in the public as a small, yet important victory for Croatia's voters, although what had started as a bottom-up citizens' initiative ended as an 'elite majority imposition' of an electoral reform. Although most goals and objectives of the said popular Initiative have not been achieved, and some

32 The OSCE/ODIHR Report on the 2011 parliamentary elections states that there were $4,504,081$ voters registered for the elections, including 411,758 registered to vote in the out-ofcountry constituency. However, preliminary census results arrived at 4,290,612 as the population of Croatia. According to some NGOs, Croatia had approximately 700,000 phantom voters at the time, due to the fictitious residence of people who do not, in reality, live in Croatia and due to the number of deceased persons in the Diaspora voter list. See "Croatia Works to Erase Phantom Voters Ahead of Sunday Elections", 17 May 2013, available at http://www.eurasiareview. com/17052013-croatia-works-to-erase-phantom-voters-ahead-of-sunday-elections/. 
constitutionally problematic aspects of the electoral system have not been eliminated (e.g., discrepancies in the number of voters between the electoral constituencies), it is also true that the citizens' initiative organization succeeded in bringing the issue of electoral reform into the public eye and that during the latter half of 2014 and early 2015 this was one of the most debated issues involving political actors, NGOs, scholars, and media commentators. The citizens' initiative to reform the electoral system had inspired several legislative drafts by various parties and independent MPs in the Parliament on the issue of changing different aspects of the electoral system, and even the then President of the Republic, Ivo Josipović, proposed a radical reform of the electoral system as a part of his campaign for the forthcoming presidential elections.

Although the citizens' initiative was not successful in achieving its foremost goal of constitutionalizing the main features of the parliamentary electoral system, it is possible that in the near future, perhaps following the parliamentary elections, the same or some other popular initiative organization will bring the issue of reforming the electoral system back into the limelight.

\section{REFERENCES}

Balkir, Canam \& Muge Aknur. 2015. Different Trajectories yet the Same Substance: Croatia and Turkey. In: Anne Wetzel \& Jan Orbie (Eds.), The Substance of EU Democracy Promotion: Concepts and Cases. New York: Routledge.

Birch, Sarah. 2009. Electoral Corruption. In: Todd Landman \& Neil Robinson (Eds.), The Sage Handbook of Comparative Politics. London: SAGE.

Birch, Sarah. 2011. Electoral Malpractice. Oxford: Oxford University Press.

Brunner, Georg. 2001. Direct vs. Representative Democracy. In: Andreas Auer \& Michael Butzer (Eds.), Direct Democracy: The Eastern and Central European Experience. Aldershot: Ashgate.

Cain, Bruce E. 2008. Democracy in the States: Experiments in Election Reform. Washington D.C.: Brookings Institution Press.

Chernykh, Svitlana, Zachary Elkins, James Melton \& Tom Ginsburg. 2014. Constitutions and Election Management. In: Pippa Norris, Richard W. Frank \& Ferran Martinez i Coma (Eds.), Advancing Electoral Integrity. Oxford: Oxford University Press.

Chryssogonos, Kostas \& Costas Stratilatis. 2012. Limits of Electoral Equality and Political Representation. European Constitutional Law Review, Vol. 8, No. 1, pp. 9-32.

Duranti, Francesco. 2014. Constitutional Dialogues in Italy, available at http://www. iconnectblog.com/2014/01/constitutional-dialogues-in-italy/ 
Eckstein, Harry. 1963. Introduction: Constitutional Engineering and the Problem of Viable Representative Government. In: H. Eckstein \& D. E. Apter (Eds.), Comparative Politics: A Reader. New York: The Free Press.

Elklit, Jørgen. 2012. What Kind of Animal is Electoral Integrity?. Paper prepared for presentation at the Pre-IPSA Workshop. Madrid: Universidad Complutense.

Elklit, Jørgen \& Palle Svensson. 1997. What Makes Elections Free and Fair. Journal of Democracy, Vol. 8, No. 3, pp. 32-46.

European Court of Human Rights. 1987. Mathieu-Mohin \& Flerfayt v. Belgium. Application no. 9267/81.

Freedom in the World. 2013. Croatia, https://freedomhouse.org/report/freedomworld/2013/croatia\#.VXbCNs_tmko

Goodwin-Gill, Guy S. 1994. Free and Fair Elections: International Law and Practice. Geneva: Inter-Parliamentary Union.

Harris, D. J., M. O’Boyle, E. P. Bates \& C. M. Buckley. 2014. Law of the European Convention on Human Rights, 3rd ed. Oxford: Oxford University Press.

Jasic, Suzana. 2000. Monitoring the Vote in Croatia. Journal of Democracy, Vol. 11, No. 4, pp. 159-168.

Jesse, Eckhard. 2008. Wahlsysteme und Wahlrecht. In: Oscar W. Gabriel \& Sabine Kropp (Eds.), Die EU-Staaten im Vergleich: Strukturen, Prozesse, Politikinhalte, 3rd ed. Wiesbaden: VS Verlag.

Kasapović, Mirjana. 2012. Voting Rights, Electoral Systems, and Political Representation of Diaspora in Croatia. East European Politics and Societies and Cultures, Vol. 26, No. 4, pp. 777-791.

Kasapović, Mirjana. 2013. Zašto je hrvatski izborni sustav dobar? (Why Croatia's Electoral System is Good?). In: Jakša Barbić (Ed.), Izbori zastupnika u Hrvatski Sabor i referendum. Zagreb: The Croatian Academy of Sciences and Arts.

Lecuyer, Yannick. 2014. The Right to Free Elections. Strasbourg: Council of Europe.

LeDuc, Lawrence. 2011. Electoral Reform and Direct Democracy in Canada: When Citizens Become Involved. West European Politics, Vol. 34, No. 3, pp. 551-567.

Lijphart, Arend. 1994. Electoral Systems and Party Systems: A Study of Twenty-Seven Democracies 1945-1990. Oxford: Oxford University Press.

Linton, Martin \& Mary Southcout. 1998. Making Votes Count: The Case for Electoral Reform. London: Profile Books.

Lutz, Georg. 2004. Switzerland: Introducing Proportional Representation from Below. In: Josep M. Colomer \& Bernard Grofman (Eds.), Handbook of Electoral System Choice. Houndmills: Palgrave Macmillan.

Matsusaka, John G. 2006. Direct Democracy and Electoral Reform. In: Michael P. McDonald \& John Samples (Eds.), The Marketplace of Democracy: Electoral Compe- 
tition and American Politics. Washington D.C.: Cato Institute/Brookings Institution Press.

Moser, Robert G. 2009. Electoral Engineering in New Democracies: Can Preferred Electoral Outcomes Be Engineered? In: Zoltan Barany \& Robert G. Moser (Eds.), Is Democracy Exportable?. Cambridge: Cambridge University Press.

Nohlen, Dieter. 2014. Wahlrecht und Parteiensystem, 7th ed. Opladen: Verlag Barbara Budrich.

Norris, Pippa. 2004. Electoral Engineering: Voting Rules and Political Behavior. Cambridge: Cambridge University Press.

Norris, Pippa. 2014a. Why Electoral Integrity Matters. Cambridge: Cambridge University Press.

Norris, Pippa. 2014b. Introduction. In: Pippa Norris, Richard W. Frank \& Ferran Martinez i Coma (Eds.), Advancing Electoral Integrity. Oxford: Oxford University Press

Norris, Pippa, Richard W. Frank \& Ferran Martinez i Coma. 2013. Assessing the Quality of Elections. Journal of Democracy, Vol. 24, No. 4, October, pp. 124-135.

Norris, Pippa, Richard W. Frank \& Ferran Martinez i Coma (Eds.). 2014. Advancing Electoral Integrity. Oxford: Oxford University Press.

O'Boyle, Michael. 2008. Electoral Disputes and the ECHR: An Overview, CDL-UD (2008)010, Strasbourg.

Omejec, Jasna. 2004. Electoral Law of the Republic of Croatia - Election of Representatives of National Minorities to the Parliament. Unidem seminar "European Standards of Electoral Law in Contemporary Constitutionalism". Sofia, 28-29 May.

OSCE/OHIDR. 2012. Croatia, Parliamentary Elections, 4 December 2011: Final Report, 3 February 2012, available at http://www.osce.org/hr/odihr/88084.

Palermo, Francesco. 2014. Wahlrechtsurteil: Italiens Verfassungsgerichthof ersetzt die Politik, 15 January. Available at http://www.verfassungsblog.de/de/wahlrechtsurteil-italiens-verfassungsgerichtshof-ersetzt-die-politik/\#.UvFdwdGA05s.

Papier, Hans-Jürgen. 2015. Die Legitimität der Fünfprozentklausel. In: Torsten Oppelland (Ed.), Das deutsche Wahlrecht in Spannungsfeld von demokratischer Legitimität und politischer Funktionalität. Berlin: Berliner Wissenschafts Verlag.

Podolnjak, Robert. 2012. What Should Be Changed in the Croatian Electoral System. Informator, No. 6053, 10 March.

Podolnjak, Robert. 2013. Suvremeni hrvatski izborni inženjering kao sofisticirani oblik izborne manipulacije (Contemporary Croatian Electoral Engineering as a Sophisticated Form of Electoral Manipulation). Zbornik Pravnog fakulteta u Zagrebu (Collected Papers of the Law Faculty in Zagreb), Vol. 63, No. 1, pp. 155-187.

Podolnjak, Robert. 2014a. On the question why basic principles of electoral system should be embedded into the Croatian constitution. Informator, No. 6334. 
Podolnjak, Robert. 2014b. Constitutional Reforms of Citizen-Initiated Referendum: Causes of Different Outcomes in Slovenia and Croatia (December 26, 2014). Available at SSRN: http://ssrn.com/abstract=2542931.

Qvortrup, Matt. 2012. Voting on Electoral Reform: A Comparative Perspective on the Alternative Vote Referendum in the United Kingdom. The Political Quarterly, Vol. 83, No. 1, pp. 108-116.

Renwick, Alan. 2010. The Politics of Electoral Reform: Changing the Rules of Democracy. Cambridge: Cambridge University Press.

Riker, William. 1984. Electoral Systems and Constitutional Restraints. In: A. Lijphart \& B. Grofman (Eds.), Choosing an Electoral System: Issues and Alternatives. Praeger, New York.

Rodin, Siniša. 2001. Country Report - Croatia. In: Andreas Auer \& Michael Butzer (Eds.), Direct Democracy: The Eastern and Central European Experience. Aldershot: Ashgate.

Rokkan, Stein. 1970. Citizens, Elections, Parties. Oslo: Universitetsforlaget.

Sartori, Giovanni. 1997. Comparative Constitutional Engineering: An Inquiry into Structures, Incentives and Outcomes, 2nd ed. New York: New York University Press.

Sturzo, Luigi. 2007. Leggi elettorali e instituzioni democratiche. In: Scritti di carattere giuridico. Discorsi e attivita parlamentare (1946-1959). Soveria Mannelli: Rubbettina.

Taagepera, Rain. 2002. Designing Electoral Rules and Waiting for an Electoral System to Evolve. In: A. Reynolds (Ed.), The Architecture of Democracy: Constitutional Design, Conflict Management, and Democracy. Oxford: Oxford University Press.

Venice Commission. 2008a. Comparative report on thresholds and other features of electoral systems which bar parties from access to parliament, CDL-AD(2008)037.

Venice Commission. 2008b. Electoral law. Strasbourg: Council of Europe Publishing.

Venice Commission. 2010. Report on thresholds and other features of electoral systems which bar parties from access to parliament (II), CDL-AD(2010)007.

Venice Commission. 2015. Report on Proportional Electoral Systems: The Allocation of Seats inside the Lists (Open/Closed Lists), CDL-AD(2015)001.

Wall, Alan \& Mohamed Salih. 2007. Engineering Electoral Systems: Possibilities and Pitfalls. The Hague: Netherlands Institute for Multiparty Democracy.

Mailing Address: Robert Podolnjak, Faculty of Law, University of Zagreb, Trg Maršala Tita 3, Zagreb.E-mail: robert.podolnjak@pravo.hr 